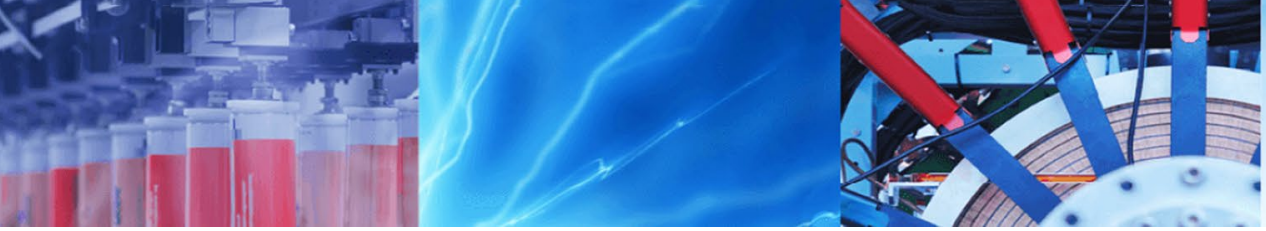

Research Article

\title{
Influence of processing on the physiochemical, functional and pasting properties of Nigerian Amaranthus viridis seed flour: a multivariate analysis approach
}

\author{
Babatunde Olawoye $^{1,2}$ (1) Saka O. Gbadamosi ${ }^{2}$
}

Received: 13 February 2020 / Accepted: 4 March 2020 / Published online: 11 March 2020

(c) Springer Nature Switzerland AG 2020

\begin{abstract}
A Nigerian Amaranthus viridis seed (Tete) was subjected to various processing conditions with the view to examining the impact of processing techniques on the nutritional, functional and pasting properties of the Amaranthus viridis seed flour. The outcome of the research demonstrated that germination fundamentally increased the nutritional as well as the functional properties of the amaranth flour while autoclaving enhanced the physical, pasting properties and flowability of the flour when compared to other processing methods. Defatted amaranth flour had the highest protein solubility when compared with other processing techniques. Likewise, germination and fermentation resulted in decrease in the degree of lightness and redness of the flour. The chemometrics analysis of the data revealed that three principal components accounted for $92.65 \%$ of the total variation of the data while the herechical clustering analysis revealed that processing of the seed led to the classification of the flour into three groups. Finally, from the study, both fermentation and germination enhanced the nutritional and functional properties of the amaranth flour and subsequently could be utilized formulation of gluten-free products and being used as functional food ingredients for weaning foods and baked products.
\end{abstract}

Keywords Pseudocereal · Amaranthus viridis · Processing methods · Flowability · Multivariate analysis

\section{Introduction}

In time past, diverse varieties and species of plants had been used as a carbon source of energy in human nutrition. This plant species predominantly used, include but not limited to cereals such as wheat, maize and rice [1]. However, owing to an untimely increase in world population, and diverse uses coupled with the industrial application of these cereal crops, there had been a search for an alternative crop with increased nutritional value as well as availability that could serve as a carbon source of energy. There is a growing concern about the utilization of grain amaranths an Andean crop, as an alternative energy source owing to their nutraceutical and nutritional properties [2].
The cultivation of Amaranth spp, a pseudocereal crop had long be dated in Central and South America and also a few regions of Asia as well as few places in Africa. In the early 1980's, there had been an increase in its cultivation and production particularly in developing countries because of its resistant to drought and other harsh weather condition [3]. Among the species of grain amaranth, Amaranthus viridis widely referred to as "tete" among Yoruba dwellers is the most widely grown specie of amaranth in Nigeria. One reason for its increase cultivation remain its leaves and grains which possess high nutritional values in comparison with other cereals plants $[2,4]$.

The utilization of Amaranthus viridis seed flour as food such as in breakfast cereal, pasta, cookies, noodles, pancakes, bread and soup or as a functional ingredient,

Babatunde Olawoye, btolawoye@gmail.com | 'Department of Food Science and Technology, First Technical University, KM 15, Ibadan-Lagos Expressway, Ibadan, Nigeria. ${ }^{2}$ Department of Food Science and Technology, Obafemi Awolowo University, Ile-Ife, Nigeria. 
however, requires the knowledge of post-harvest characteristics and functional attributes of the seed flour. These functional attributes had been defined according to Kinsella and Melachouris [5] as those physiochemical attributes that affect the behavioural characteristics of the food macromolecules in food systems. The knowledge these properties in Amaranthus viridis seed flour are desirable for its utilization as food or functional food ingredient.

While previous studies focus on the physiochemical properties of the other Amaranthus spp (Amaranthus cruentus by Menegassi et al. [6]; Amaranthus caudatus by Peiretti et al. [7]), there is, be that as it may, dearth of information on functional attributes of Nigerian Amaranthus viridis grain as affected by processing conditions. These data are fundamental in determining the potential use of grain amaranth as a food or functional food ingredient. The objective of this study was to examine how processing techniques influence the functional attributes of flour obtained from Nigerian grain amaranth.

\section{Materials and methods}

\subsection{Material}

Grain amaranth was purchased at Ondo town market, Ondo state, Nigeria. The identity of the grain was affirmed at the herbarium of the Department of Botany, Obafemi Awolowo University lle-Ife, Nigeria. The grains were sorted and sieved to remove extraneous materials such as stone, shaft and leaves from the grain. The grains were preserved in a container devoid of air under refrigeration at $4{ }^{\circ} \mathrm{C}$ prior to analysis.

\subsection{Methods}

\subsubsection{Fermentation}

The fermentation of the Amaranthus viridis was done using techniques proposed by lgbabul et al. [8]. Briefly, the previously cleaned grain was steep in warm water $\left(45^{\circ} \mathrm{C}\right)$ for $9 \mathrm{~h}$ with constant changing of the water at $3 \mathrm{~h}$ interval. The Soaked seeds were then transferred into calabash pots and allowed to ferment inside an incubator (Biobase, BJPX-HIII, USA) at $30^{\circ} \mathrm{C}$ for $72 \mathrm{~h}$. After fermentation, the was dried using a hot-air oven (Uniscope, SM9053, England) at $50^{\circ} \mathrm{C}$ for $8 \mathrm{~h}$. The fermented sample was subsequently milled and passed through sieve $(200 \mu \mathrm{m})$. After milling, the sample was stored in a Ziploc polyethene nylon which was then placed inside a refrigerator until further use.

\subsubsection{Germination}

The method described by Elkhalifa and Bernhardt [9] was used for the germination of the grain amaranth.

\subsubsection{Autoclaving}

A previously cleaned amaranth grain was subjected to autoclaving $\left(121^{\circ} \mathrm{C}\right.$ for $\left.15 \mathrm{~min}\right)$, followed by oven drying at $50^{\circ} \mathrm{C}$ for $8 \mathrm{~h}$. The samples were commuted using a domestic grinder and subsequently stored in $\mathrm{n}$ a Ziploc polyethene nylon which was then placed inside a refrigerator until further use.

\subsubsection{Blanching}

The method described by Olawoye and Gbadamosi [2] was used for the blanching operation. Briefly, the blanching of the sample (grain amaranth) was done using hot water bath (Julabo SW22, Germany) operating at $75^{\circ} \mathrm{C}$ for $5 \mathrm{~min}$. After blanching, the water was drained-off of the amaranth grain using a sieve cloth and subsequently dried at $50^{\circ} \mathrm{C}$ for $8 \mathrm{~h}$ using a hot-air oven. The dried grains were milled using Marlex Excella grinder (United Kingdom), stored in air tight container under refrigeration at $4{ }^{\circ} \mathrm{C}$ before the time of use.

\subsubsection{Defatting}

The defatting process was done using a cold extraction method described by Fasasi et al. [10]. Cleaned grain amaranth was milled into fine flour and the fat extraction process was done by subjecting the milled flour into acetone (flour to the solvent ratio $1: 5 \mathrm{w} / \mathrm{v}$ ) and stirred over a magnetic stirrer for $5 \mathrm{~h}$. The slurry was then filtered through a Whatman No. 1 filter paper and re-extracted twice in the same manner. The defatted flour was desolventized by subjecting it to drying in Gallenkamp oven (OVB 305, United Kingdom) at $50^{\circ} \mathrm{C}$ for $8 \mathrm{~h}$. The dried flour was finely ground in a Marlex Excella grinder set at high speed to obtain homogenous defatted flours. The defatted flours obtained was stored in airtight container and put in refrigeration at $4{ }^{\circ} \mathrm{C}$ before the time of use. The flow chart for the production of fermented, germinated, blanched, cooked and whole Amaranth grain flour is shown in Fig. 1.

\subsection{Proximate composition}

Proximate compositions which consist of moisture content, crude protein (Kjeldahl method), crude fat (solvent extraction), crude fibre and ash of the Amaranthus viridis seed flours were determined using the standard procedures of Association of Official Analytical Chemists [11]. 
Amaranth grain<smiles>[3H]C</smiles>

Cleaning and Sorting

(To remove extraneous materials)

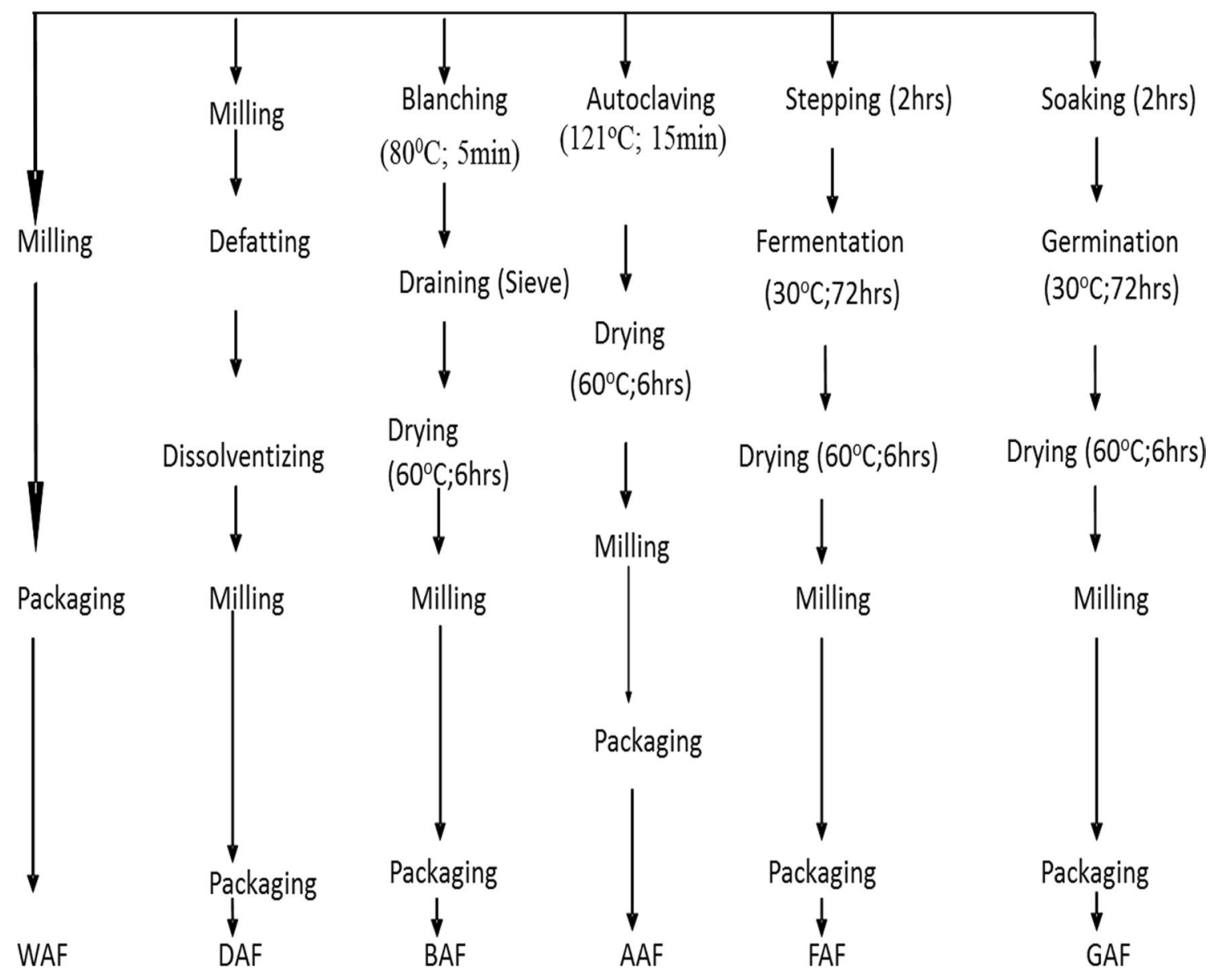

Fig. 1 Flow chart for amaranth flour processing

The carbohydrate content was determined by difference as shown in the equation below:

Carbohydrate. Total carbohydrate content was determined by the difference. flour samples was mixed with $1 \mathrm{~mL}$ of $95 \%$ ethanol and $9 \mathrm{~mL}$ of $1 \mathrm{M} \mathrm{NaOH}$. The mixture was vortex and made up to $100 \mathrm{~mL}$ with distilled water. Five millilitre of the solution was mixed with $2 \mathrm{~mL}$ of iodine solution $\left(0.2 \% \mathrm{I}_{2}\right.$

Carbohydrates $=(100-(\%$ Crude Proteins $+\%$ Lipids $+\%$ Ash $+\%$ Crude fibre $+\%$ Moisture $)$.

\subsection{Amylose content}

The amylose content of the seed flour was evaluated using the method of Juliano [12]. Briefly, $100 \mathrm{mg}$ of the and $2 \% \mathrm{KI}$ ) and the absorbance was measured at $620 \mathrm{~nm}$ (Bosh 72S UV-Vis spectrophotometer, Thermoscientific, USA). The amylose content was obtained from the calibration curve. The amylose from corn starch was used as a standard. 


\subsection{Physical properties of the processed flour}

\subsubsection{Bulk density and flowability of the processed four}

Packed and loose bulk densities were evaluated using the method prescribed by Mpotokwane et al. [13]. Briefly, $10 \mathrm{~mL}$ granulated cylinder was filled to mark with the processed Amaranthus flour. The measuring cylinder was tapped on a laboratory bench top until no further diminution of the sample level. The packed bulk density was calculated as the ratio of the weight of the flour to the volume of the flour after tapping. While the loose bulk density was determined by filling the $10 \mathrm{~mL}$ granulated cylinder to mark without tapping the cylinder [14].

Carr index and Hausner ratio [15] was used as the index of flowability of the processed flour as shown in the equation below.

Carr index $(\%)=100\left(\frac{\text { Packed bulk density }- \text { Loose bulk density }}{\text { Loose bulk density) }}\right)$

Hausner ratio $=($ Packed bulk density/Loose bulk density $)$

Carr (1965) categorize the values (\%) 5-10, 12-16, 18-21, and 23-28 as excellent, good, fair and poor flow properties respectively.

\subsubsection{True density}

Liquid displacement method of Thompson and Isaacs [16] was used for true density determination and the value was calculated using the equation below:

True density $=\frac{\text { volume of tulene displaced }}{\text { Weight of the sample }}$

The porosity was obtained using the equation below:

Porosity $=\frac{\text { True density }- \text { bulk density }}{\text { true density }}$

\subsection{3 $\mathrm{pH}$}

The $\mathrm{pH}$ was measured using $10 \%(\mathrm{w} / \mathrm{v})$ suspension of the sample in distilled water. The suspension was thoroughly mixed and the $\mathrm{pH}$ of the suspended solution was measured with a Hanna checker pH meter (Model HI1270). The $\mathrm{pH}$ meter was standardized using a $\mathrm{pH}$ buffer.

\subsubsection{Colour determination}

The colour which include $L^{*}$, lightness $(0=$ black, $100=$ white $), a^{*}(-a=$ greenness, $+a=$ redness $)$ and $b^{*}$ $(-b=$ blueness, $+b=$ yellowness) of the amaranth flours were obtained using HunterLab colorimeter coupled with an optical sensor (HunterLab, U.S.A.). The instrument was calibrated as follows; $L^{*}=96.9$, $a^{*}=-0.04$, $b^{*}=1.84$. Flour colour index, yellow index, browning index, the degree of whiteness $(\% \mathrm{~W})$, colour intensity $(\Delta \mathrm{E})$, hue angle $\left(\mathrm{H}^{*}\right)$ and delta chroma $(\Delta \mathrm{C})$ were calculated from the result using the equation below [17-20].

$$
\begin{aligned}
& \Delta \mathrm{C}=\left(\Delta \mathrm{a}^{* 2}+\Delta \mathrm{b}^{* 2}\right)^{0.5} \\
& \Delta \mathrm{E}=\left(\Delta \mathrm{L}^{* 2}+\Delta \mathrm{a}^{* 2}+\Delta \mathrm{b}^{* 2}\right)^{0.5} \\
& \mathrm{H}^{*}=\tan ^{-1}\left(\mathrm{~b}^{*} / \mathrm{a}^{*}\right) \\
& \mathrm{W}(\%)=100-\left[\left(100-\mathrm{L}^{*}\right)^{2}+\left(\left(\mathrm{a}^{*}\right)^{2}+\left(\mathrm{b}^{*}\right)^{2}\right)\right]^{0.5}
\end{aligned}
$$

Flour colour index $(\mathrm{FCl})=L^{*}-b^{*}$

Browning Index $=\frac{100(X-0.31)}{0.71}$

$X=\frac{\left(a^{*}+1.75 L^{*}\right)}{\left(5.465 L^{*}+a^{*}-3.012 b^{*}\right)}$

Yellow Index $=\frac{142.86 b^{*}}{L^{*}}$

\subsection{Functional properties of the processed flour}

\subsubsection{Foaming capacity and Stability}

Foaming capacity coupled with the foam stability was determined using the modified method of Pearce and Kinsella [21]. Briefly, $5 \mathrm{~g}$ of the flour sample was weighed into an electric blender (O'Qlink, SN2200, China) already containing $100 \mathrm{~mL}$ of distilled water. The sample was homogenized at $4000 \mathrm{rpm}$ for $5 \mathrm{~min}$. The mixture was immediately transferred into a $200 \mathrm{~mL}$ graduated cylinder and the volume attained by the foam was measured. Foaming capacity was expressed as the percentage of foam volume at inception $(0 \mathrm{~min})$. Foam stability was expressed as foam volume (\%) remaining after $30 \mathrm{~min}$. 


\subsubsection{Emulsifying capacity and stability}

Emulsifying capacity and stability were determined by the procedure provided by Lin et al. [22] as modified by Shevkani et al. [23].

\subsubsection{Water absorption capacity (WAC) and oil absorption capacity (OAC)}

Water absorption capacity (WAC) and oil absorption capacity (OAC) were determined as described by SzeTao and Sathe [24]. $1 \mathrm{~g}$ of each flour sample was weighed into a pre-weighed $25 \mathrm{~mL}$ centrifuge tube and $10 \mathrm{~mL}$ of distilled water were added. Samples were vortexed for one min before being transferred into a centrifuge for centrifugation at $4000 \mathrm{~g}$ for $15 \mathrm{~min}$. Excess water was decanted and the tubes were inverted at an angle of $45^{\circ}$. For oil absorption, $10 \mathrm{~mL}$ of refined sunflower oil was used in place of water. The weights of water/bound oil samples were determined by difference.

\subsubsection{Swelling factor $(Q)$}

The swelling factor ( $Q$ ) was determined using the method of Bagley and Christianson [25]. Processed Amaranthus flour ( $5 \mathrm{~g}$ ) was weighed into already preweighed $25 \mathrm{~mL}$ centrifuge tube containing $20 \mathrm{~mL}$ of distilled water. The sample was vortex for a minute and allowed to stand at room temperature for $10 \mathrm{~min}$ followed by gelatinization at $70^{\circ} \mathrm{C}$ for $30 \mathrm{~min}$. the gelatinized flour was centrifuged in a centrifuge at $4000 \mathrm{~g}$ for $10 \mathrm{~min}$. Swelling factor $(\mathrm{Q})$ is determined as the ratio of the weight after either soaking or gelatinization to their dry weight as shown in the equation below.

$Q(g / g)=\frac{\text { Weight hydrated (gelatinised) granules }}{\text { Dry weight of flour }}$

\subsubsection{Determination of sediment volume fraction}

The volume fraction of the seed flour was measured according to the centrifugation method of Hemar et al. [26] and Ahmed et al. [27] using water. One gram of the flour sample was weighed into a $25 \mathrm{~mL}$ centrifuge tube and vortex for $1 \mathrm{~min}$. The tube containing the sample was centrifuge at $4000 \mathrm{~g}$ for $20 \mathrm{~min}$. After centrifugation, the total height $\mathrm{H}_{\mathrm{T}}$ of the sample and the height of the sediment $\mathrm{H}_{\mathrm{S}}$ were measured, and the volume fraction, $\varphi$ occupied by the flour was expressed as given in the equation below:

$\phi=\frac{H_{T}}{H_{S}}$

The Equation above is valid only for closely packed particles devoid of interstitial space.

\subsubsection{Least gelation concentration (LGC)}

The method described by Sathe and Salunkhe [28] as modified by Gbadamosi et al. [29] was used for the least gelation concentration. A flour concentration $1 \%, 3 \%, 5 \%$, $7 \%, 9 \%, 11 \%, 13 \%, 15 \%, 17 \%$ and $20 \%(\mathrm{w} / \mathrm{v})$ of each flour sample was dispersed in $20 \mathrm{~mL}$ test tubes. The test tubes containing these suspensions was vortex, heated for $1 \mathrm{~h}$ in a boiling water bath (Julabo, SW22, Germany) and rapidly cooled under running tap water. The cooled tubes were then placed in refrigeration for $2 \mathrm{~h}$. After refrigeration, the tubes were inverted and the LGC is the minimum concentration at which the cooked and subsequently cooled sample from the inverted tube did not fall or slip from the wall of the tube.

\subsection{Protein solubility}

Protein solubility was determined by the method described by Gbadamosi et al. [29]. Amaranth samples $(2.5 \mathrm{~g})$ were each dispersed in $500 \mathrm{~mL}$ conical flask containing $250 \mathrm{~mL}$ distilled water. The dispersion was stirred on a magnetic stirrer (Cenco, Netherland) at $150 \mathrm{rpm}$ for $2 \mathrm{~h}$ at $30^{\circ} \mathrm{C}$. After stirring, the dispersion was centrifuged (Bosch centrifuge TDL-5, Sweden) at $3500 \times g$ for $30 \mathrm{~min}$ and then filtered through Whatman No.1 filter paper. An aliquot of the filtrate was centrifuged at $4000 \times \mathrm{g}$ for $20 \mathrm{~min}$ and the resulting filtrate obtained was labelled supernatant 1 . The $\mathrm{pH}$ of the remaining filtrate $(20 \mathrm{~mL})$ each was adjusted to $\mathrm{pH} 2,4,6,8$ and 10 with $1 \mathrm{M} \mathrm{HCl}$ or $\mathrm{NaOH}$. The supernatant was collected and the soluble protein was determined by the procedure of Lowry et al. [30] The percentage of soluble protein was calculated and plotted against the corresponding $\mathrm{pH}$ values.

\subsection{Determination of pasting properties}

Pasting properties were determined using the Rapid Visco Analyzer (RVA- 4, Newport Scientific Pty Ltd., Warriewood, NSW, Australia) with Thermocline for windows software (AACC, 1999). Four grams of flour was suspended in $25 \mathrm{~mL}$ of distilled water in an RVA canister. The canister was loaded into the RVA and analyzed with a constant speed $(3 \mathrm{~g})$. The holding viscosity, peak viscosity, final 
viscosity, and pasting temperature of amaranth flour was determined.

\section{Result and discussion}

\subsection{Proximate composition}

The result of the effect of processing methods on proximate composition of Amaranthus viridis seed flour is presented in Table 1. The moisture content of amaranth flour increased significantly $(p<0.05)$ after fermentation and germination. The increase in the moisture content might be due to the release of water by the fermenting organism during the hydrolysis of the macromolecule. This is similar to the findings of Jan et al. [31] who reported an increase in the moisture content of germinated chenopodium. The protein content of the processed amaranth seed sample varied between $8.98 \pm 0.20 \%$ for autoclaved amaranth flour (AAF) and $18.07 \pm 0.47 \%$ of germinated amaranth flour (GAF). However, the protein content of both germinated and fermented wheat flour samples was significantly similar and higher when compared to other amaranth samples $(p<0.05)$. This observation agreed with findings of Osman [32] that processing techniques such as germination and fermentation improved the nutritional quality of the food products, mostly in terms of protein content. This finding could also be attributed to the fact that during germination, the microorganisms in food utilized the carbohydrate content in the food sample to synthesise amino acid needed for their growth and development [33]. There was significant $(p<0.005)$ decrease in crude fat content from $7.10 \%$ to $5.5 \%$ from WAF and FAF respectively. However, a slight increase in crude fat was observed in AAF sample which could due to disruption of the cell structure and membrane partitions by heat during autoclaving causing the fat to liquefy and be easily released from the seed. The decrease in fat content observed during fermentation and germination might be attributed to the activities of lypolytic enzymes during these processes as reported by Fasasi et al. [10] which led to the hydrolysis of fat into fatty acid and glycerol. Fermentation had a profound effect on the carbohydrate content exhibiting the lowest value (55.29\%) followed by germination. The decrease in the carbohydrate content during fermentation could be due to enzymatic breakdown of carbohydrate to simpler sugars during fermentation. Jan et al. [34] also reported a similar reduction in total carbohydrate and starch content during the fermentation of chenopodium seed. The amylose content of fermented and germinated samples was found to be significantly less than other processed sample, a reason which could be attributed to the utilization of the amylose as a carbon source of energy for fermenting and germinating microorganism.

\subsection{Physiochemical properties}

The effect of processing on the physical properties of the processed amaranth flour is presented in Table 2 . The result revealed significant $(p<0.05)$ difference in the physical properties of the flour. Fermentation and germination significantly lower the loose and packed bulked density of the flour. This reduction could be attributed to the breaking down of higher molecular weight macromolecules to small chain macromolecules by the fermenting and germinate microorganism. In their report, Jan et al. [31] found that germination significantly lowers the bulk density of Chenopodium album. In contrast, both the loose and packed density significantly increased by $2.6 \%$ and $11.6 \%$, respectively when the amaranth grains were subjected to blanching and autoclaving. The high bulk density of autoclaved amaranth flour (AAF) could be attributed to the pre-gelatinization of starch granule embedded in the seed during heating thereby leading to the closure of the airspace between the pores. This result compared favourably with the report of Adegunwa et al. [35]) who reported

Table 1 Proximate Composition (\%) of the Amaranthus viridis Flour Samples

\begin{tabular}{|c|c|c|c|c|c|c|c|}
\hline Sample & Moisture & Ash & Protein & Fat & Fibre & Carbohydrate & Amylose (\%) \\
\hline AAF & $8.66 \pm 0.66^{b}$ & $2.12 \pm 0.03^{d}$ & $8.98 \pm 0.20^{d}$ & $7.65 \pm 0.08^{\mathrm{a}}$ & $3.11 \pm 0.50^{c}$ & $69.46 \pm 1.02^{\mathrm{a}}$ & $19.31 \pm 0.13^{a}$ \\
\hline GAF & $10.33 \pm 0.13^{a}$ & $5.06 \pm 0.34^{\mathrm{a}}$ & $18.07 \pm 0.47^{\mathrm{a}}$ & $5.65 \pm 0.16^{b}$ & $5.59 \pm 0.48^{\mathrm{a}}$ & $55.29 \pm 0.28^{b}$ & $14.28 \pm 0.09^{b}$ \\
\hline FAF & $10.82 \pm 0.50^{a}$ & $4.00 \pm 0.87^{b}$ & $17.07 \pm 0.47^{a}$ & $5.50 \pm 0.07^{b}$ & $5.44 \pm 0.27^{a}$ & $57.16 \pm 1.03^{b}$ & $13.07 \pm 0.29^{b}$ \\
\hline BAF & $8.83 \pm 0.31^{b}$ & $2.60 \pm 0.31^{d}$ & $10.16 \pm 0.63^{c}$ & $7.30 \pm 0.13^{a}$ & $3.43 \pm 0.08^{c}$ & $67.66 \pm 1.08^{a}$ & $18.64 \pm 0.31^{a}$ \\
\hline WAF & $10.16 \pm 0.67^{a}$ & $2.94 \pm 0.09^{c}$ & $11.06 \pm 0.97^{c}$ & $7.10 \pm 0.21^{a}$ & $3.70 \pm 0.75^{b}$ & $65.01 \pm 1.14^{\mathrm{a}}$ & $18.21 \pm 0.75^{a}$ \\
\hline DAF & $9.50 \pm 0.04^{b}$ & $3.34 \pm 1.10^{c}$ & $14.51 \pm 0.18^{b}$ & $1.95 \pm 0.37^{c}$ & $4.30 \pm 0.91^{b}$ & $66.40 \pm 0.91^{\mathrm{a}}$ & $18.93 \pm 0.62^{a}$ \\
\hline
\end{tabular}

Values are means of three replicates \pm standard deviation. $(n=3)$

Values in the row with the same letter in superscript are not significantly different from each other $(p \leq 0.05)$

$A A F$ autoclaved amaranth flour, GAF germinated amaranth flour, FAF fermented amaranth seed, BAF blanched amaranth flour, WAF whole amaranth flour, DAF defatted amaranth flour 
Table 2 Physical Properties of the Processed Amaranthus viridis Seed Flour

\begin{tabular}{|c|c|c|c|c|c|c|c|c|}
\hline Sample & $\mathrm{pH}$ & $\mathrm{LBD}(\mathrm{g} / \mathrm{mL})$ & PBD $(\mathrm{g} / \mathrm{mL})$ & $\mathrm{HR}$ & $\mathrm{Cl}(\%)$ & $\mathrm{TD}(\mathrm{g} / \mathrm{mL})$ & Porosity & Flowabilty \\
\hline AAF & $6.1 \pm 0.07^{\mathrm{a}}$ & $0.86 \pm 0.06^{\mathrm{a}}$ & $0.98 \pm 0.03$ & $1.13 \pm 0.04^{\mathrm{a}}$ & $13.37 \pm 0.95^{d}$ & $1.34 \pm 0.01^{\mathrm{a}}$ & $26.90 \pm 1.24^{d}$ & Good \\
\hline GAF & $5.41 \pm 0.12^{b}$ & $0.66 \pm 0.02^{b}$ & $0.80 \pm 0.01$ & $1.26 \pm 0.03^{\mathrm{a}}$ & $26.41 \pm 1.86^{a}$ & $1.52 \pm 0.01^{\mathrm{a}}$ & $45.53 \pm 2.75^{a}$ & Poor \\
\hline FAF & $5.21 \pm 0.09^{b}$ & $0.68 \pm 0.01^{b}$ & $0.83 \pm 0.03$ & $1.21 \pm 0.01^{\mathrm{a}}$ & $20.78 \pm 2.01^{b}$ & $1.49 \pm 0.04^{\mathrm{a}}$ & $46.17 \pm 2.90^{\mathrm{a}}$ & Fair \\
\hline BAF & $6.19 \pm 0.04^{\mathrm{a}}$ & $0.82 \pm 0.06^{\mathrm{a}}$ & $0.94 \pm 0.05$ & $1.15 \pm 0.07^{a}$ & $14.63 \pm 0.89^{d}$ & $1.38 \pm 0.01^{\mathrm{a}}$ & $31.81 \pm 2.72^{C}$ & Good \\
\hline WAF & $6.24 \pm 0.13^{a}$ & $0.77 \pm 0.02^{\mathrm{a}}$ & $0.89 \pm 0.02$ & $1.16 \pm 0.06^{\mathrm{a}}$ & $16.42 \pm 0.73^{c}$ & $1.43 \pm 0.02^{\mathrm{a}}$ & $37.64 \pm 3.02^{b}$ & Fair \\
\hline DAF & $5.98 \pm 0.01^{\mathrm{a}}$ & $0.69 \pm 0.01^{b}$ & $0.78 \pm 0.01$ & $1.13 \pm 0.05^{\mathrm{a}}$ & $12.68 \pm 0.99^{\mathrm{e}}$ & $1.41 \pm 0.03^{\mathrm{a}}$ & $44.86 \pm 4.42^{\mathrm{a}}$ & Good \\
\hline
\end{tabular}

Values are means of three replicates \pm standard deviation. $(n=3)$

Values in the row with the same letter in superscript are not significantly different from each other ( $p \leq 0.05)$

$A A F$ autoclaved amaranth flour, GAF germinated amaranth flour, FAF fermented amaranth seed, BAF blanched amaranth flour, WAF whole amaranth flour, DAF defatted amaranth flour, $L B D$ loose bulk density, $P B D$ packed bulk density, HR Hausner ratio, $C I C a r r$ index, $T D$ true density

a significant difference when comparing between the bulk density of roasted, raw and autoclaved beniseed flour. Loose bulk density correlates significantly $(p<0.01)$ to packed bulk density $(0.946)$ and porosity $(-0.993)$ but significantly $(p<0.05)$ correlate to true density $(-0.898)$ as shown in Table 6. Packed density on the other hand exhibit significant $(p<0.01)$ correlation with loose bulk density $(0.946)$ and porosity $(-0.971)$. The true density of the amaranth flour increased with germination with no significant difference $(p<0.05)$ in the true density of the amaranth flour. There is a significant $(p<0.05)$ correlation between true density and loose bulk density $(-0.898)$, Hausner ratio (0.900), Carr index (0.904), porosity (0.860), as well as the $\mid L^{*}$ value.

\subsubsection{Flowability property}

The effect of processing on the flow properties of the amaranth flour is presented in Table 2. Germinated amaranth flour had the highest Hausner ratio (1.26), Carr index (26.41\%) and porosity, hence, poor flowability. Autoclaved amaranth flour showed lower Hausner ratio, Carr index as well as lowest porosity and hence good flowability. The Hausner ratio and Carr index are considered as an indirect measurement of powder or particle flow property and the higher the values, the more cohesive the substance is [36]. The higher porosity of the germinated flour indicates poor flowability and hence more inter-particulate space where water could be absorbed. Hausner ratio correlates significantly $(p<0.01)$ with Carr index $(1.000)$ and significantly $(p<0.05)$ with true density $(0.900)$ while Carr index correlates significantly $(p<0.05)$ with true density $(0.904)$. Porosity shows significant $(p<0.01)$ correlation with loose bulk density $(-0.993)$ and packed bulk density $(-0.971)$. it also correlated significantly $(p<0.860)$ with true density (Table 6.).

\subsubsection{Colour characteristics}

The Hunter colour values $\left(L^{*}, a^{*}, b^{*}\right)$ of the amaranth flour as affected by processing is presented in Table 3. Among the processed flour, autoclave amaranth flour was significantly lighter (high $L^{*}$ ) and redder (4.08) when compared with other processed flour. Fermented amaranth flour was observed to be less bright (lower $L^{*}$ value), greener (negative $a^{*}$ value), and more yellow (higher $b^{*}$ value) than other processed amaranth flour. The decrease in lightness observed in both germinated and fermented amaranth flour could be as a result of the production of dark pigments and breakdown of carbohydrate and protein to facilitate Maillard browning reaction during drying which may had occurred during fungal growth. Also, the metabolism of sugar which led to the production of organic acid by fermenting and germinating microorganism may have brought about the darkening of the product colour. The result also revealed that the hue angle of all processed amaranth flour was lower than $90^{\circ}$ with fermented amaranth flour having the highest value $\left(86.87^{\circ}\right)$. According to Prinyawiwatkul et al. [37] hue angles of $0^{\circ}, 90^{\circ}$, and $180^{\circ}$ were categorized to represent red, yellow and green hue respectively. Food samples or flours within $0^{\circ}-90^{\circ}$ tends to exhibit orange-red colour while flours within $90^{\circ}-180^{\circ}$ tends towards greenish yellow colour. Fermented amaranth flour had the highest hue angle $\left(86.65^{\circ}\right)$, its colour tends to be greenish-yellow owing to its less brightness $\left(L^{*}=66.47\right)$, highest yellowness $\left(b^{*}=12.81\right)$, highest greenness $\left(a^{*}=-0.70\right)$ and highest saturation (chroma $\left.=12.82\right)$. A yellow-orange colour was observed in autoclaved flour when compared to untreated amaranth flour (WAF) which tends to exhibit orange colour. The change in colour of the amaranth flour during fermentation and germination process could serve as an advantage during the incorporation of the flour into certain food such as pastry, extruded snacks and baked goods. Hue angle correlates significantly 


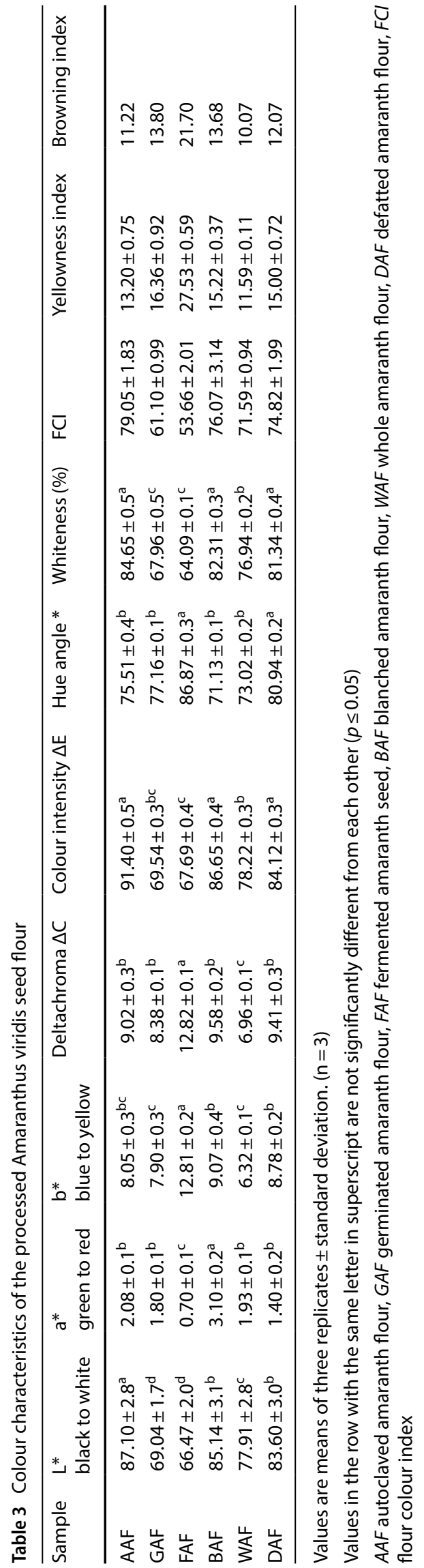

$(p<0.01)$ with $a^{*}$ value $(-0.958), b^{*}$ value $(0.939)$ and significantly $(p<0.05)$ with chroma $(0.901)$.

\subsection{Functional properties}

\subsubsection{Foaming properties}

The effect of processing on the foam capacity and stability of amaranth flour is presented in Table 4. Significant $(p<0.05)$ difference exit in the foaming properties of the processed amaranth flour with the exception of germinated, fermented and whole flour which was not significant in their foaming capacity. The foaming properties (i.e. capacity and stability) of flour depends generally on the surface tension formed by proteins which keeps air bubbles in suspension and slows down the rate of coalescence. Foaming properties is also a function of methods of processing, protein type, carbohydrate, pH e.t.c. The foaming properties were found to increase significantly during germination and fermentation of the amaranth seed. This increase could be as a result of an increase in solubilised protein during germination and fermentation which invariably increased the foaming properties. Also, "germination and fermentation may have caused surface denaturation of the proteins and reduced the surface tension of the molecules, which have good foamability" [9]. The foaming capacity and stability reported in this research were found to be lower than that reported by Shevkani et al. [23] on Amaranthus hypochondriacus $L$. The foaming properties of the processed amaranth flour affirm its suitability as a functional ingredient in food products where foaming is desirable such as ice-cream. As revealed in Table 6., foaming capacity significantly $(p<0.05)$ correlate with packed bulk density $(-0.854)$ while foaming stability correlate significantly $(p<0.01)$ with loose bulk density $(-0.949)$, packed bulk density $(-0.976)$ and porosity $(0.959)$.

\subsubsection{Emulsifying properties}

EAl indicates the ability of the proteins to induce the formation of the newly created dispersed particles in emulsions, whereas ESI value reflects the ability of food protein to form an emulsion that can withstand stress and remain unchanged over a stipulated period of time, under specific conditions [5]. The emulsion properties depend on the type, concentration and solubility of the proteins [38]. Germination was found to significantly increase significant $(p<0.05)$ the emulsion activity (EA) and stability (ES) of the amaranth flour, and when compared with the raw amaranth flour sample. There was an increase of $145 \%$ and $142 \%$ for the two properties after germination. This result conforms to the report of Akubor and Obiegbuna [39] that germination increased the EA and ES of millet flour. These 
Table 4 Functional Properties of the Processed Amaranthus viridis seed flour

\begin{tabular}{|c|c|c|c|c|c|c|c|c|c|}
\hline Samples & $\mathrm{FC}(\%)$ & FS (\%) & $\operatorname{EAI}\left(\mathrm{m}^{2} / \mathrm{g}\right)$ & ESI (\%) & OAC $(\mathrm{g} / \mathrm{g})$ & WAC $(\mathrm{g} / \mathrm{g})$ & $Q(g / g)$ & $\Phi$ & LGC (\%) \\
\hline$A F$ & $6.63 \pm 0.27^{d}$ & $4.08 \pm 0.16^{d}$ & $20.92 \pm 1.62^{d}$ & $31.97 \pm 0.93^{c}$ & $0.88 \pm 0.01^{\mathrm{a}}$ & $2.20 \pm 0.05^{\mathrm{a}}$ & $3.56 \pm 0.01^{\mathrm{a}}$ & $31.42 \pm 0.84^{\mathrm{a}}$ & 7 \\
\hline GAF & $36.03 \pm 0.20^{\mathrm{a}}$ & $25.33 \pm 0.34^{\mathrm{a}}$ & $67.10 \pm 2.12^{\mathrm{a}}$ & $93.30 \pm 3.21^{\mathrm{a}}$ & $1.00 \pm 0.02^{\mathrm{a}}$ & $2.33 \pm 0.03^{\mathrm{a}}$ & $3.13 \pm 0.01^{b}$ & $21.74 \pm 0.61^{c}$ & 7 \\
\hline$A F$ & $31.41 \pm 0.67^{b}$ & $26.66 \pm 0.13^{a}$ & $57.83 \pm 1.11^{b}$ & $84.60 \pm 1.70^{a}$ & $0.95 \pm 0.02^{\mathrm{a}}$ & $2.39 \pm 0.05^{b}$ & $3.10 \pm 0.03^{b}$ & $20.92 \pm 0.92^{c}$ & 5 \\
\hline BAF & $12.99 \pm 0.14^{c}$ & $3.65 \pm 0.23^{d}$ & $27.48 \pm 1.40^{c}$ & $38.47 \pm 0.09^{b}$ & $0.89 \pm 0.01^{\mathrm{a}}$ & $2.16 \pm 0.01^{\mathrm{a}}$ & $3.40 \pm 0.02^{\mathrm{a}}$ & $28.08 \pm 0.83^{a}$ & 13 \\
\hline . & $29.19 \pm 1.62^{b}$ & $10.29 \pm 1.24^{c}$ & $31.48 \pm 1.29^{c}$ & $45.39 \pm 1.19^{b}$ & $0.90 \pm 0.02^{\mathrm{a}}$ & $2.00 \pm 0.02^{b}$ & $3.26 \pm 0.02^{b}$ & $26.59 \pm 0.76^{b}$ & 11 \\
\hline DAF & $30.47 \pm 0.96^{\mathrm{b}}$ & $21.55 \pm 1.58^{b}$ & $58.92 \pm 0.67^{a}$ & $75.40 \pm 2.10^{a}$ & $0.91 \pm 0.02^{\mathrm{a}}$ & $2.21 \pm 0.07^{\mathrm{a}}$ & $3.34 \pm 0.02^{\mathrm{ab}}$ & $26.87 \pm 0.55^{b}$ & 9 \\
\hline
\end{tabular}

Values are means of three replicates \pm standard deviation. $(n=3)$

Values in the row with the same letter in superscript are not significantly different from each other $(p \leq 0.05)$

$A A F$ autoclaved amaranth flour, GAF germinated amaranth flour, FAF fermented amaranth seed, BAF blanched amaranth flour, WAF whole amaranth flour, $D A F$ defatted amaranth flour, $F C$ foam capacity, FS foam stability, EAl emulsion activity index, ESI emulsion stability index, OAC oil absorption capacity, WAC water absorption capacity, Q: Swelling factor; $\Phi$ : Sediment volume fraction, LGC least gelation concentration

results, however, contradict the report of Gamel et al. [40] that germination decreased emulsion stability of amaranth flour. The increase in the emulsifying properties during germination may have been caused by the hydrolysis and partial unfolding of polypeptides thus exposing the hydrophobic sites of amino acids, which aids hydrophobic association of the peptide chains with the lipid droplets, so that the net result was that a much greater volume/ surface area of protein was made available, and emulsification capacity was enhanced $[5,41]$. Table 6 . showed there exist significant $(p<0.01)$ correlation between emulsion activity index and loose bulk density (-0.944), packed bulk density (-0.949) with loose bulk density $(-0.952)$, packed bulk density $(-0.955)$ and porosity $(0.944)$.

\subsubsection{Water absorption capacity and oil absorption capacity}

The effect of processing on water absorption capacity and oil absorption capacity of amaranth flour is revealed in Table 4. Water absorption capacity of whole amaranth flour (WAF) was observed to be $2.0 \mathrm{~g} / \mathrm{g}$, while fermentation and germination caused significantly $(p<0.05)$ increase in WAC of amaranth flour by $19.5 \%$ and $16.5 \%$ respectively. This result, however, contradicts the report of Gamel et al. [40] who found that germination reduces the water absorption capacity of amaranth seed dried at $30^{\circ} \mathrm{C}$. In their research work, Echendu et al. [42] reported the dependency of water absorption capacity of flour upon protein, carbohydrate and their interaction as well as nature. An increase of WAC on fermentation could be attributed to an increase in protein content and change in the quality of protein upon fermentation and also a breakdown of polysaccharide molecules; hence the sites for interaction with water and holding water would be increased. The high WAC of autoclaving conforms to the report of Sharma et al. [43] who reported an increase in WAC of roasted barley. The increase in water absorption capacity might be due to an increased level of damaged starch which was induced by gelatinization of starch during autoclaving and blanching [44]. The formation of a porous structure which absorbs and holds water by capillary action might also be a reason for the increase in WAC [43].

Germination increase slightly the oil absorption capacity (OAC) of amaranth flour when compared to other processing methods but no significant $(p<0.05)$ difference in the increase (Table 4). This result is similar to that of Akubor and Obiegbuna [39] who reported an increase in OAC for germinated millet flour. Since the binding of the oil depends on the surface availability of hydrophobic amino acids [45], the enhancement in oil-absorption capacities of the germinated sample could be attributed to an increase in the availability of these amino acids by unmasking the non-polar residues from the interior protein molecules. OAC has been attributed to the physical entrapment of oil. This is important since fat acts as a flavouring retainer and increases the mouthfeel of food [5]. OAC correlate significantly $(p<0.05)$ with loose bulk density $(-0.914)$, Hausner ratio (0.877), Carr index (0.885), porosity $(0.866)$ and $L^{*}$ value $(-0.833)$. Also, significant $(p<0.01)$ correlation exist between $\mathrm{OAC}$ and True density.

\subsubsection{Swelling factor and sediment volume fraction}

The ability of the starch granule of flour to swell freely during heating in water is the swelling factor. The result of the swelling factor of the amaranth flour as affected by processing methods is shown in Table 4. There was a considerable increase in the swelling factor of the amaranth flour due to autoclaving when compared to other processing methods. The increase as a result of autoclaving could be due to an increased level of damaged starch which was induced by partial gelatinization of starch. This caused the formation of a porous structure which absorbs and hold 
water by capillary action and hence enhances swelling [43]. The swelling factor correlates significantly $(p<0.05)$ with loose bulk density $(0.888)$, porosity $(-0.874)$, and true density $(-0.970)$ at $p<0.01$.

The sediment volume fraction of the amaranth flour suspended in aqueous dispersion at $25^{\circ} \mathrm{C}$ is presented in Table 4. According to the result, autoclaved amaranth flour had the highest volume fraction while germinated amaranth flour was observed to exhibit the lowest volume fraction. The sediment volume fraction is the measure of the total volume of dispersed particle suspended in aqueous or dispersed phase [27]. The increased as a result of autoclaving might be due to partial gelatinization of the flour allowing greater porosity and fluid entrapment [46]. Table 6. showed SVF significantly $(p<0.05)$ correlate with loose bulk density $(0.903)$, Hausner ratio $(-0.836)$, Carr index $(-0.838)$, porosity $(-0.874), L^{*}$ value $(0.815)$, whiteness $(0.836)$ and significantly $(p<0.01)$ with true density $(-0.971)$

\subsubsection{Least gelation concentration}

The least gelation concentration (LGC) which is defined as the minimum flour concentration at which gel remain stable in an inverted tube was used as an index of gelation capacity. A lower LGC reflects better gelation ability of the flour [47]. The least gelation concentration (Table 4) of the fermented amaranth flour (5\%) which is the least among all the samples followed by germinated amaranth flour (7\%). Autoclaved amaranth flour had the highest least gelation concentration. The LGC of the fermented flour is in agreement with the result of Elkhalifa et al. [48] who reported $6 \%$ for sorghum flour fermented for $24 \mathrm{~h}$. Gelation is an aggregation of denatured molecules. The low gelation concentration observed in fermented and germinated amaranth flour could be a result of higher amylase and protease enzyme activities on the starch and protein fractions of the amaranth flour which lead to lower least gelation concentration required to form a stable gel. These results suggest that amaranth flour subjected to fermentation and germinated would be a good gel-forming or firming agent and would be useful in food systems such as pudding and snacks which require thickening and gelling.

\subsection{Protein solubility}

The most critical functional property of protein is protein solubility because other protein properties such as foaming and emulsifying properties are affected by it [5]. The result of the protein solubility of the processed amaranth flour samples at various $\mathrm{pH}$ values (2-10) is shown in Fig. 2. All the processed amaranth flours exhibit minimum protein solubility at $\mathrm{pH} 4$ which correspond to the isoelectric

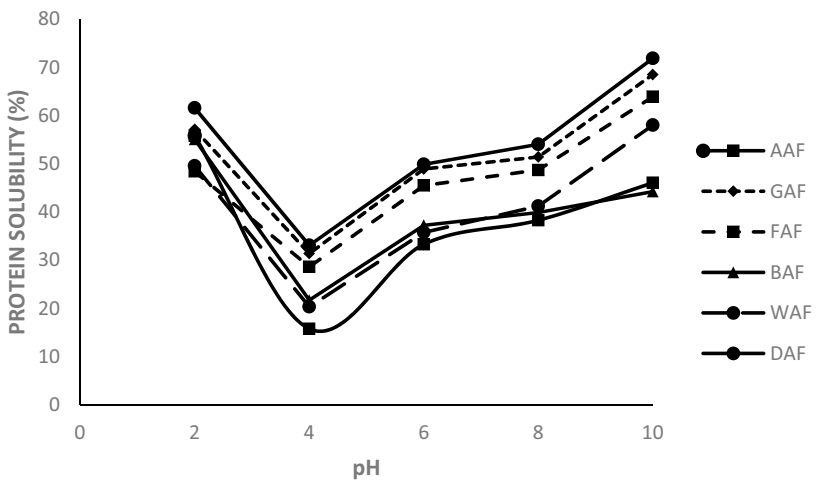

Fig. 2 Effect of $\mathrm{pH}$ on protein solubility of processed Amaranthus viridis seed flour (AAF, GAF, FAF, BAF, WAF and DAF)

point ( $\mathrm{pl}$ ) of the processed flours. The solubility of the processed Amaranthus viridis seed flour increased as the $\mathrm{pH}$ increased from isoelectric point. Defatted amaranth flour (DAF) had the highest protein solubility of $71.85 \%$ at $\mathrm{pH}$ 10 while BAF had the lowest protein solubility (44.25\%) at the same $\mathrm{pH}$ when compared to other processed seed flours. Based on this protein solubility profile; WAF, DAF, BAF, FAF, GAF and AAF were least soluble $(20.37 \%, 33.09 \%$, $21.72 \%, 28.64 \%, 31.39 \%$ and $15.81 \%$ respectively) at $\mathrm{pH} 4$ and are most soluble at $\mathrm{pH} 10$. Protein solubility characteristics are influenced by factors such as origin, processing conditions, $\mathrm{pH}$, ionic strength and the presence of other ingredients [5].

\subsection{Pasting characteristics}

The effect of processing on the pasting characteristics of the amaranth flour is presented in Table 5 . There was significant $(p<0.05)$ difference in the pasting characteristics of the processed flour. Fermentation was observed to cause a significant decrease in the peak viscosity, peak time, peak temperature, final viscosity breakdown viscosity setback and trough viscosity of the amaranth flour. There was also a decrease in the pasting profile as a result of germination of the amaranth flour. The report correlates with the report of Jan et al. [31] that germination reduces the pasting properties of Chenopodium album. The reduction in the pasting profile of fermented and germinated amaranth flour could be as a result of the activation of an endogenous enzyme such as alpha and beta amylase which hydrolysis starch into smaller molecules (sugar). Zhu et al. [49] reported that pasting profile of flour is strongly affected by starch content, amylopectin-amylose ratio, protein amylase and lipids. The high amylose content of autoclaved amaranth flour could be the reason for increase pasting profile (Table 6). 
Table 5 Pasting properties of the processed Amaranthus virids seed flour

\begin{tabular}{llllllll}
\hline Sample & Peak viscosity $(\mathrm{cP})$ & Peak time $(\mathrm{min})$ & $\begin{array}{l}\text { Peak temperature } \\
\left({ }^{\circ} \mathrm{C}\right)\end{array}$ & Final viscosity $(\mathrm{cP})$ & $\begin{array}{l}\text { Breakdown } \\
\text { viscosity }(\mathrm{cP})\end{array}$ & $\begin{array}{l}\text { Setback viscosity } \\
(\mathrm{cP})\end{array}$ & $\begin{array}{l}\text { Trough viscosity } \\
(\mathrm{CP})\end{array}$ \\
\hline AAF & $941 \pm 9.30^{\mathrm{a}}$ & $8.3 \pm 0.10^{\mathrm{a}}$ & $89.47 \pm 1.00^{\mathrm{a}}$ & $1810 \pm 10.50^{\mathrm{a}}$ & $39.8 \pm 0.60^{\mathrm{a}}$ & $869 \pm 5.80^{\mathrm{a}}$ & $901.2 \pm 9.00^{\mathrm{a}}$ \\
GAF & $778 \pm 8.50^{\mathrm{c}}$ & $5.9 \pm 0.10^{\mathrm{b}}$ & $83.91 \pm 0.90^{\mathrm{a}}$ & $1267 \pm 9.60^{\mathrm{a}}$ & $24.1 \pm 0.30^{\mathrm{b}}$ & $489 \pm 8.10^{\mathrm{d}}$ & $753.9 \pm 8.70^{\mathrm{b}}$ \\
FAF & $714 \pm 6.70^{\mathrm{d}}$ & $5.7 \pm 0.20^{\mathrm{b}}$ & $78.1 \pm 1.10^{\mathrm{b}}$ & $1194 \pm 11.30^{\mathrm{f}}$ & $26.6 \pm 0.30^{\mathrm{b}}$ & $480 \pm 6.50^{\mathrm{d}}$ & $687.4 \pm 6.80^{\mathrm{c}}$ \\
BAF & $873 \pm 9.00^{\mathrm{b}}$ & $7.2 \pm 0.10^{\mathrm{a}}$ & $86.23 \pm 0.80^{\mathrm{a}}$ & $1503 \pm 9.10^{\mathrm{c}}$ & $35.7 \pm 0.70^{\mathrm{a}}$ & $630 \pm 9.30^{\mathrm{c}}$ & $837.3 \pm 9.40^{\mathrm{ab}}$ \\
WAF & $841 \pm 10.20^{\mathrm{b}}$ & $6.5 \pm 0.20^{\mathrm{b}}$ & $85.78 \pm 0.90^{\mathrm{a}}$ & $1328 \pm 10.80^{\mathrm{d}}$ & $33.8 \pm 0.40^{\mathrm{a}}$ & $487 \pm 4.90^{\mathrm{d}}$ & $807.2 \pm 8.80^{\mathrm{b}}$ \\
DAF & $943 \pm 11.70^{\mathrm{a}}$ & $7.5 \pm 0.10^{\mathrm{a}}$ & $86.01 \pm 0.50^{\mathrm{a}}$ & $1645 \pm 11.00^{\mathrm{b}}$ & $36.03 \pm 0.70^{\mathrm{a}}$ & $702 \pm 7.60^{\mathrm{b}}$ & $906.9 \pm 10.20^{\mathrm{a}}$
\end{tabular}

Values are means of three replicates \pm standard deviation. $(n=3)$

Values in the row with the same letter in superscript are not significantly different from each other $(p \leq 0.05)$

$A A F$ Autoclaved amaranth flour, GAF germinated amaranth flour, FAF fermented amaranth seed, BAF blanched amaranth flour, WAF whole amaranth flour, DAF defatted amaranth flour

Table 6 Pearson's correlation between physical and functional properties of the processed amaranth flour

\begin{tabular}{|c|c|c|c|c|c|c|c|c|c|c|c|c|c|}
\hline Variak & $B D$ & PBD & $\mathrm{Hr}$ & $\mathrm{Cl}$ & TD & Porosity & I & A & $b$ & $\Delta C$ & $\Delta \mathrm{E}$ & $\mathrm{H}$ & $\% W$ \\
\hline- & 0.725 & b & - & 0.002 & S & 797 & -0.221 & -0.269 & 0.039 & -0.014 & -0.222 & 0.216 & -0.205 \\
\hline D & $-0.949^{a}$ & $-0.976^{a}$ & 0.448 & 0.461 & 0.741 & $0.959^{a}$ & -0.579 & -0.423 & 0.286 & 0.240 & -0.578 & 0.388 & -0.578 \\
\hline $\mathrm{Al}$ & $-0.944^{a}$ & $-0.949^{a}$ & 0.501 & 0.510 & 0.739 & $0.937^{\mathrm{a}}$ & -0 & -0.376 & 0.334 & 0.292 & -0.509 & 0.399 & -0.522 \\
\hline SI & $-0.952^{a}$ & $-0.955^{a}$ & 0.512 & 0.521 & 0.752 & $0.944^{a}$ & -0.550 & -0.420 & 0.373 & 0.330 & -0.546 & 0.437 & -0.563 \\
\hline OAC & $-0.914^{b}$ & -0.747 & $0.877^{b}$ & $0.855^{b}$ & $0.962^{a}$ & $0.866^{b}$ & -0 & -0.482 & 0.210 & 0.143 & $-0.838^{b}$ & 0.376 & $-0.823^{b}$ \\
\hline WAC & -0.583 & -0.482 & 0.573 & 0.574 & 0.544 & 0.514 & -0.626 & -0.592 & 0.759 & 0.754 & -0.610 & 0.668 & -0.680 \\
\hline $\mathrm{Q}$ & $0.888^{b}$ & 0.742 & -0.803 & -0.805 & $-0.970^{a}$ & $-0.874^{b}$ & 0.789 & 0.743 & -0.382 & -0.294 & 0.787 & -0.632 & 0.797 \\
\hline Ф & $0.903^{b}$ & 0.749 & $-0.836^{b}$ & $-0.838^{b}$ & $-0.971^{a}$ & $-0.874^{b}$ & $0.815^{b}$ & 0.776 & -0.498 & -0.419 & 0.810 & -0.701 & $0.836^{b}$ \\
\hline
\end{tabular}

${ }^{a}$ Significant correlation at $1 \%$ level

${ }^{\mathrm{b}}$ Significant correlation at $5 \%$ level

FC foam capacity, FS foam stability, EAl emulsion activity index, ESI emulsion stability index, OAC oil absorption capacity, WAC water absorption capacity; Q: Swelling factor; $\Phi$ : Sediment volume fraction, $L B D$ loose bulk density, PBD Packed bulk density, HR Hausner ratio, CI Carr index, $T D$ true density, $\triangle \mathrm{C}$ : Deltachroma; $\triangle \mathrm{E}$ : Colour intensity; $\mathrm{H}^{*}$ : Hue angle; $\mathrm{W}: \%$ whiteness

Values in bold are different from 0 with a significance level alpha $=0.05$

\subsection{Multivariate analysis of physicochemical, functional, pasting properties of the grain amaranth}

Among the chemometrics techniques used in extracting information from original data, Principal component analysis is the most commonly used. The result of the multivariate analysis revealed that the first three component accounted for $92.65 \%$ of the total variability of the data in which, $71.18 \%$ of the total variation was accounted by component 1 while component 2 accounted for 12.37 variation, and final, $9.10 \%$ of the total variance was accounted for by component 3. The information extracted from the factor loadings revealed that the principal component 1 was characterized by all the physiochemical, functional and pasting parameter except for relative breakdown and $b$ (degree of blueness or yellowness) which was characterized by principal component 2 , while fat is characterized by principal component 3 . The factor scores on the other hand revealed that the processing of the grain amaranth led to the characterization of the amaranth flour into two components. Principal component 1 was dominated by Autoclaved, germinated, blanched, defatted and fermented grain amaranth flour while only whole amaranth flour was characterized in principal component 2. Cañeque et al. [50] in their report on the interpretation of biplot denoted that there exists a positive correlation among measurements when they are close to each other otherwise, the farther the measurement is to each other, the negatively correlated the parameters is. Measurements or attribute at a distance of $90^{\circ}$ to each other is said to be independent of each other. Owing to this, fermented and germinated amaranth flour which lies at the negative side of principal component 1 (Fig. 3) formed a cluster with stability ratio, Hausner ratio, Car index, true density, porosity, foaming capacity and stability, emulsifying activity and 


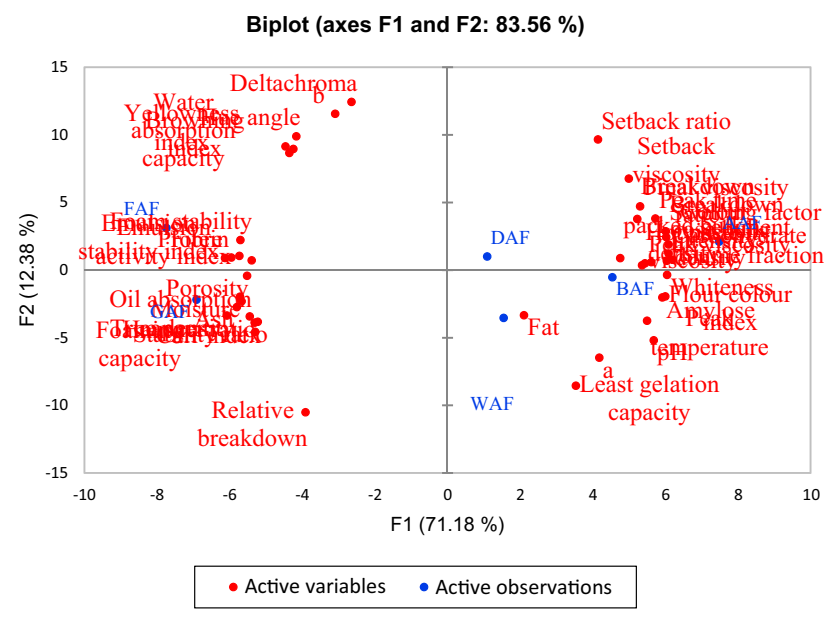

Fig. 3 Biplot of the physicochemical, functional and pasting parameters of the grain amaranth flour

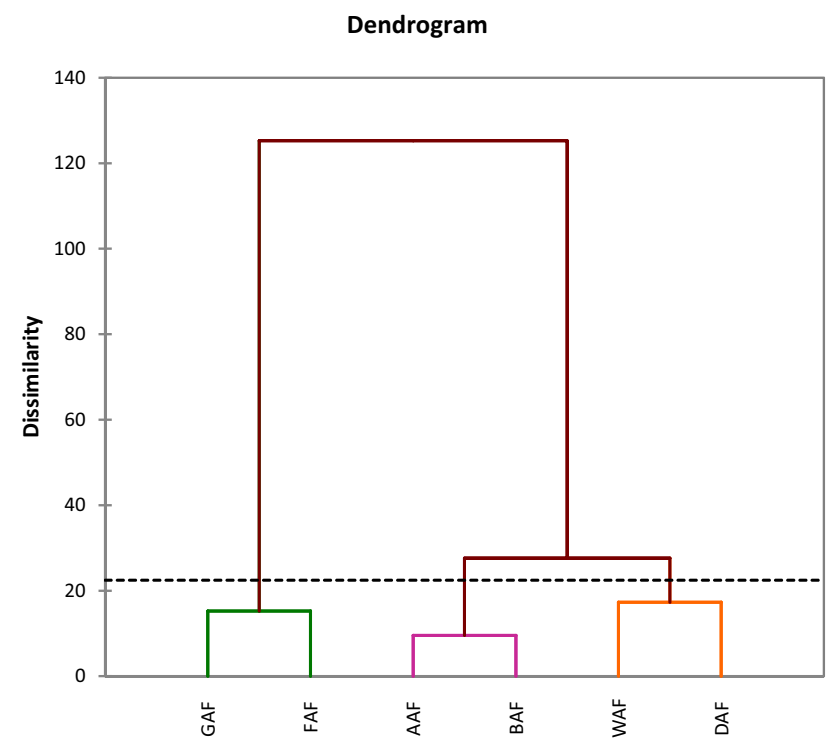

Fig. 4 Herechical clustering analysis of the grain amaranth flour

stability index, oil absorption capacity, moisture, protein and fibre, hence their correlation with these parameters. Autoclaved and blanched amaranth flour however, lies at the positive side of the component one and formed clustering with peak viscosity and time, final and breakdown viscosity, breakdown ratio, L (degree of lightness), colour intensity, whiteness, flour colour index, $\mathrm{pH}$, loose and packed bulk density, swelling factor carbohydrate and amylose content. The clustering of the parameters with $\mathrm{AAF}$ and BAF is an indication of strong and positive correction with these parameters. The result of the herechical clustering analysis (HCA) of the grain amaranth which was based on eucliean distance is shown in Fig. 4. Based on the HCA, the flour is categorized into three (3) classes.
Class 1 is being characterized by FAF and GAF, while flour samples that was categorized in class 2 include WAF and DAF. Finally, BAF and AAF are being characterized in class 3. Grain amaranth flour samples which fell into the same class tends to have similar physiochemical, functional and pasting properties.

\section{Conclusion}

In conclusion, processing methods significantly affect the nutritional, physical, functional and pasting properties of Nigerian Amaranthus viridis flour. Among the processing methods, germination and fermentation significantly influence the nutritional, functional as well as the pasting properties of the amaranth flour. Owing to it's higher nutritional and functional properties, germinated and fermented flour can be used to design gluten-free products for people with celiac disease as well as being used as a functional ingredient in the production of weaning foods and baked products.

\section{Compliance with ethical standards}

Conflict of interest The authors declare that they have no conflict of interest.

\section{References}

1. Schoenlechner R, Siebenhandl S, Berghofer E (2008) Pseudocereals. In: Gluten-free cereal products and beverages. Elsevier, $p$ 149-VI

2. Olawoye BT, Gbadamosi SO (2017) Effect of different treatments on in vitro protein digestibility, antinutrients, antioxidant properties and mineral composition of Amaranthus viridis seed. Cogent Food Agric 3(1):1296402

3. Saxena R et al (2007) Antioxidant activity of commonly consumed plant foods of India: contribution of their phenolic content. Int J Food Sci Nutr 58(4):250-260

4. Ulbricht $C$ et al (2009) An evidence-based systematic review of amaranth (Amaranthus spp.) by the natural standard research collaboration. J Dietary Suppl 6(4):390-417

5. Kinsella JE, Melachouris N (1976) Functional properties of proteins in foods: a survey. Crit Rev Food Sci Nutr 7(3):219-280

6. Menegassi B, Pilosof AM, Arêas JA (2011) Comparison of properties of native and extruded amaranth (Amaranthus cruentus L.-BRS Alegria) flour. LWT Food Sci Technol 44(9):1915-1921

7. Peiretti PG et al (2017) Antioxidative activities and phenolic compounds of pumpkin (Cucurbita pepo) seeds and amaranth (Amaranthus caudatus) grain extracts. Nat Prod Res 31(18):2178-2182

8. Igbabul B, Idikwu H, Inyang C (2012) Mucuna sloanei and Detarium microcarpum. J Food Technol 10(3):83-86

9. Elkhalifa AEO, Bernhardt R (2010) Influence of grain germination on functional properties of sorghum flour. Food Chem 121(2):387-392 
10. Fasasi O, Eleyinmi A, Oyarekua M (2007) Effect of some traditional processing operations on the functional properties of African breadfruit seed (Treculia africana) flour. LWT Food Sci Technol 40(3):513-519

11. A.O.A.C. (2005) Official methods of analysis of the Association of analytical Chemists International

12. Juliano B (1971) A simplified assay for milled rice amylase. Cereal Sci Today $16: 360$

13. Mpotokwane $S$ et al (2008) Physical properties of bambara groundnuts from Botswana. J Food Eng 89(1):93-98

14. Asoegwu S, Ohanyere S, Kanu O, Iwueke C (2006) Physical properties of African oil bean seed (Pentaclethra macrophylla). CIGR J

15. Carr RL (1965) Evaluating flow properties of solids. Chem Eng (Jan) 18:163-168

16. Thompson $R$, Isaacs $G$ (1967) Porosity determinations of grains and seeds with an air-comparison pycnometer. Trans ASAE 10(5):693-0696

17. Das I, Das S, Bal SJJOFE (2004) Specific energy and quality aspects of infrared (IR) dried parboiled rice. J Food Eng 62(1):9-14

18. Rhim J et al (1999) Physical characteristics of a composite film of soy protein isolate and propyleneglycol alginate. J Food Sci 64(1):149-152

19. Falade KO, Ayetigbo OE (2015) Effects of annealing, acid hydrolysis and citric acid modifications on physical and functional properties of starches from four yam (Dioscorea spp.) cultivars. Food Hydrocolloids 43:529-539

20. Maskan MJ (2001) Kinetics of colour change of kiwifruits during hot air and microwave drying. J Food Eng 48(2):169-175

21. Pearce KN, Kinsella JE (1978) Emulsifying properties of proteins: evaluation of a turbidimetric technique. J Agric Food Chem 26(3):716-723

22. Lin MJ-Y, Humbert E, Sosulski F (1974) Certain functional properties of sunflower meal products. J Food Sci 39(2):368-370

23. Shevkani K et al (2014) Physicochemical, pasting, and functional properties of amaranth seed flours: effects of lipids removal. $J$ Food Sci 79(7):C1271-C1277

24. Sze-Tao K, Sathe S (2000) Functional properties and in vitro digestibility of almond (Prunus dulcis L.) protein isolate. Food Chem 69(2):153-160

25. Bagley E, Christianson D (1982) Swelling capacity of starch and its relationship to suspension viscosity-effect of cooking time, temperature and concentration. J Text Stud 13(1):115-126

26. Hemar $Y$ et al (2011) Small-deformation rheology investigation of rehydrated cell wall particles-xanthan mixtures. Food Hydrocolloids 25(4):668-676

27. Ahmed J et al (2014) Effect of particle size and temperature on rheological, thermal, and structural properties of pumpkin flour dispersion. J Food Eng 124:43-53

28. Sathe S, Salunkhe D (1981) Functional properties of the great northern bean (Phaseolus vulgaris L.) proteins: emulsion, foaming, viscosity, and gelation properties. J Food Sci 46(1):71-81

29. Gbadamosi SO, Abiose SH, Aluko RE (2012) Amino acid profile, protein digestibility, thermal and functional properties of Conophor nut (Tetracarpidium conophorum) defatted flour, protein concentrate and isolates. Int J Food Sci Technol 47(4):731-739

30. Lowry $\mathrm{OH}$ et al (1951) Protein measurement with the Folin phenol reagent. J Biol Chem 193(1):265-275

31. Jan R, Saxena D, Singh S (2016) Pasting, thermal, morphological, rheological and structural characteristics of Chenopodium (Chenopodium album) starch. LWT Food Sci Technol 66:267-274
32. Osman MA (2011) Effect of traditional fermentation process on the nutrient and antinutrient contents of pearl millet during preparation of Lohoh. J Saudi Soc Agric Sci 10(1):1-6

33. Ghumman A, Kaur A, Singh N (2016) Impact of germination on flour, protein and starch characteristics of lentil (Lens culinari) and horsegram (Macrotyloma uniflorum L) lines. LWT Food Sci Technol 65:137-144

34. Jan R, Saxena D, Singh S (2015) Physico-chemical and textural property of starch isolated from Chenopodium (Chenopodium album) grains. Cogent Food Agric 1(1):1095052

35. Adegunwa M, Adebowale A, Solano E (2012) Effect of thermal processing on the biochemical composition, antinutritional factors and functional properties of beniseed (Sesamum indicum) flour. Am J Biochem Mol Biol 2(3):175-182

36. Riley CK et al (2008) The interplay between yam (Dioscorea sp) starch botanical source, micromeritics and functionality in paracetamol granules for reconstitution. Eur J Pharm Biopharm 70(1):326-334

37. Prinyawiwatkul W et al (1996) Fermented cowpea flour: production and characterization of selected physico-chemical properties. J Food Process Preserv 20(4):265-284

38. Achinewhu S (1983) Protein and food potential of African oil bean (Pentaclethra macrophylla) and velvet bean (Mucunauries). J Food Sci 47:1736-1742

39. Akubor P, Obiegbuna J (1999) Certain chemical and functional properties of ungerminated and germinated millet flour. J Food Sci Technol 36(3):241-243

40. Gamel TH et al (2006) Seed treatments affect functional and antinutritional properties of amaranth flours. J Sci Food Agric 86(7):1095-1102

41. Nir l et al (1994) Surface properties and emulsification behavior of denatured soy proteins. J Food Sci 59(3):606-610

42. Echendu C, Onimawo I, Adieze S (2004) Production and evaluation of doughnuts and biscuits from maize-pigeon pea flour blends. Niger Food J 22(1):147-153

43. Sharma $P$, Gujral HS, Rosell CM (2011) Effects of roasting on barley $\beta$-glucan, thermal, textural and pasting properties. J Cereal Sci 53(1):25-30

44. Sharma P, Gujral HS (2013) Extrusion of hulled barley affecting $\beta$-glucan and properties of extrudates. Food Bioprocess Technol 6(6):1374-1389

45. Sosulski F et al (1976) Functional propreties of rapeseed flours, concentrates and isolate. J Food Sci 41(6):1349-1352

46. Catsimpoolas N (1970) Gelation phenomena of soybean globulins: protein-protein interactions. Cereal Chem 47:559-570

47. Akintayo E, Oshodi A, Esuoso K (1999) Effects of $\mathrm{NaCl}$, ionic strength and $\mathrm{pH}$ on the foaming and gelation of pigeon pea (Cajanus cajan) protein concentrates. Food Chem 66(1):51-56

48. Elkhalifa AEO, Schiffler B, Bernhardt R (2005) Effect of fermentation on the functional properties of sorghum flour. Food Chem 92(1):1-5

49. Zhu L-J et al (2010) Underlying reasons for waxy rice flours having different pasting properties. Food Chem 120(1):94-100

50. Cañeque V, Pérez C, Velasco S, Dıaz M, Lauzurica S, Álvarez I, Ruiz de Huidobro F, Onega E, De la Fuente J (2004) Carcass and meat quality of light lambs using principal component analysis. Meat Sci 67(4):595-605

Publisher's Note Springer Nature remains neutral with regard to jurisdictional claims in published maps and institutional affiliations. 